\title{
Avoiding Greenwashing in Event Marketing: An Exploration of Concepts, Literature and Methods
}

\author{
Kai-Michael Griese ${ }^{1}$, Kim Werner $^{1} \&$ Johannes Hogg ${ }^{2}$ \\ ${ }^{1}$ School of Management, University of Applied Science, Osnabrück, Germany \\ ${ }^{2}$ School of Management, Fresenius University of Applied Science, Hamburg, Germany \\ Correspondence: Kai-Michael Griese, School of Management, University of Applied Science, Osnabrück, \\ Germany, Caprivistraße 30a, Tel: 49-541-969-3880. E-mail: k-m.griese@hs-osnabrueck.de
}

$\begin{aligned} & \text { Received: August 25, } 2017 \quad \text { Accepted: September 20, } 2017 \quad \text { Online Published: October 25, } 2017 \\ & \text { doi:10.5539/jms.v7n4p1 }\end{aligned}$ URL: http://doi.org/10.5539/jms.v7n4p1

\begin{abstract}
Greenwashing, defined by the Oxford Dictionary as "disinformation disseminated by an organization so as to present an environmentally responsible public image" can cause multifarious problems for companies. The phenomenon of greenwashing has, however, not attracted much attention in the event marketing literature to date. The purpose of this paper is twofold. It first describes and analyses the specific characteristics and features of greenwashing in event marketing. It then seeks to identify the current fundamental approaches of how to avoid greenwashing in event marketing and to assess their potential. A two-step literature analysis with complementary search approaches served as a methodical framework. First, journals related to event marketing were screened for the keywords "greenwashing" and "greenwash". Next, the general literature was consulted for the same keywords. The results clearly demonstrate that the subject of greenwashing has been widely neglected in the event literature. There appears to be no overall concept or approach that allows event actors to avoid greenwashing, albeit various individual initiatives exist. However, it also became clear that initiatives against greenwashing in event marketing can be developed and implemented in the short and long term, for example by integrating different stakeholders. Additional political and juridical efforts based on specific guidelines are also necessary to prevent greenwashing in the future. The study is the first one to provide a systematic approach to the topic of greenwashing in the context of event marketing, including relevant approaches for its avoidance. It can thus help practitioners to better detect and avoid greenwashing in the event industry and to guide similar research in the future.
\end{abstract}

Keywords: greenwashing, event marketing, event, multi-stakeholder, eco-labeling

\section{Introduction}

In recent years, the number of companies that share their environmental activities with their stakeholders has increased (e.g., Lane, 2014; Lyon \& Montgomery, 2015; Schmidt \& Donsback, 2012). Some of these companies communicate their sustainable activities in their external marketing communication, even though they do not deliver to the extent claimed (e.g., terrachoice 2007, 2009, 2010). This misleading behaviour towards customers, in which the companies present themselves and their actions better than they actually are, is referred to as "greenwashing" (Horiuchi \& Schuchard, 2009; Parguel, Benoit-Moreau, \& Larceneux, 2011). Studies by terrachoice (2010) analysed and assessed statements about environmentally friendly products in the US and revealed inconsistent message claims in 95 percent of all products tested, thus indicating the scope of greenwashing (terrachoice, 2010).

Greenwashing also appears to be important in event marketing. Over the last decade, a variety of events have tried to build an image and reputation for their green efforts, as for example festivals like Glastonbury, Coachella, or Burning Man, or recent mega-events like the London Olympics. On one hand, greenwashing is concerned with events, which allegedly use sustainable products, or companies they present. For instance, Europe's largest carmaker Volkswagen routinely used events to promote the eco-friendliness of their car models (e.g., Blue Motion), which eventually ended up becoming a good example of greenwashing in 2015. Due to manipulated software, the actual $\mathrm{CO}_{2}$ emissions of certain car models were significantly higher than originally communicated at these events (e.g., at the Detroit Auto Show January 2011, Jurnecka, 2011). On the other hand, greenwashing also concerns the communication about the organisation and implementation of different events. The Olympic 
Games in Athens in 2004 is labelled a "Green Event" by the Organization Committee for the Athens Olympic (ATHOC), but this was only partially true (e.g., no wind power plants were used and the buildings had no solar power; Greenpeace, 2004).

There are diverse consequences of greenwashing. Recent studies demonstrate that misrepresentative marketing communication of companies regarding the "green" quality of their products leads to negative direct and indirect word of mouth. At the same time, the perceived "green" quality of the product decreases (Chen, Lin, \& Chang, 2014) as well as the likelihood of re-purchases (Kalafatis \& Pollard, 1999; Rahman, Park \& Geng-Qing Chi, 2015). Such behaviour cannot only cause harm to the company (Miras-Rodríguez, Carrasco-Gallego, \& Escobar-Pérez, 2015; Walker \& Wan, 2012; Xingqiang, 2015), but can also jeopardise the credibility of all companies which address environmental aspects in their external brand communication (Alves; 2009; Chen et al., 2014; Polansky, Grau, \& Garma, 2010). There is the imminent risk that customers who are confronted with perpetual greenwashing activities by companies react with disorientation towards environmental information, which ultimately leads to a general decrease in confidence towards "green" statements (Chen \& Chang, 2013; Hamann \& Kapelus, 2004).

In summary, greenwashing is a serious problem. Although greenwashing has been discussed in the general literature for many years (e.g., Bruno, 1992; Lane 2014), surprisingly few studies exist in the event management literature. The aim of this article is to provide an overview on greenwashing practices in the event industry and to identify potential event marketing approaches to avoid future greenwashing activities.

\section{Literature Review}

\subsection{Characteristics of Greenwashing in Event Marketing}

While no widely accepted definition of the term "greenwashing" exists in the literature, previous studies (Bowen \& Aragon-Correa, 2014; Lyon \& Montgomery, 2015) have agreed on some typical characteristics (a-e) of greenwashing.

A basic feature of greenwashing is (a) the objective function of an environmentally friendly image ("green image") of a company (cf. Bruno, 1992; Parguel et al., 2011). The company seeks to improve its image to gain greater acceptance among stakeholders such as investors, customers or potential employees (e.g., Montoro-Rios, Luque-Martinez, \& Rodriguez-Molina, 2008). Thus, the importance of an eco-friendly image of an event is closely linked to the increasing relevance of such an image for the intended target group of the company.

Based on the observation that the envisaged environmental image and the actual image are not identical in some companies, greenwashing can be understood as (b) misleading communication by and about a company (Laufer, 2003; Lyon \& Maxwell, 2006; Parguel et al., 2011). Table 1 outlines typical misleading communication strategies for customers in the context of event marketing. The greenwashing report (terrachoice, 2010) for the US and Canada demonstrated that abstract and vague statements as well as a lack of evidence were used most frequently. Greenwashing is most effective if the target groups are unable to adequately judge the information. This lack (c) of assessment capability occurs if there is only limited information available about the company, if information cannot be factually assessed or if subliminal messages are unrecognizable (e.g., Chen \& Chang, 2013; Mitchell \& Papavassiliou, 1999).

Table 1. Strategies of greenwashing in event marketing

\begin{tabular}{|c|c|}
\hline $\begin{array}{l}\text { Strategies } \\
\text { Greenwashing }\end{array}$ & Description of an example in the Event Market \\
\hline Hidden goal conflicts & $\begin{array}{l}\text { One single environmentally friendly activity of an event operator is communicated to the target group } \\
\text { although other activities are not environmentally friendly. }\end{array}$ \\
\hline Lack of evidence & $\begin{array}{l}\text { Statements about an environmentally friendly performance of an event are communicated without being } \\
\text { substantiated by scientific evidences. }\end{array}$ \\
\hline Abstract, vague statements & $\begin{array}{l}\text { Communication deliberately uses abstract terms which can be easily misinterpreted in favour of an } \\
\text { environmentally friendly image (e.g. green, environmentally friendly, or ECO-Event). }\end{array}$ \\
\hline Wrong labels/slogans & Companies or institutes invent labels in order to increase the creditability of an event. \\
\hline Irrelevance & $\begin{array}{l}\text { The company uses reasons which are relatively irrelevant for the event itself but are generally regarded as } \\
\text { environmentally friendly (e.g. CFC-free). }\end{array}$ \\
\hline Design elements & $\begin{array}{l}\text { The design used in the event communication (colours, pictures etc.) gives an environmentally friendly } \\
\text { impression (e.g. colour green, meadows). }\end{array}$ \\
\hline
\end{tabular}

Source: e.g., TerraChoice, 2010; Furlow, 2010; Thomas, 2014; Lyon \& Montgomery, 2015. 
Another feature of greenwashing is (d) to downplay the amount of natural resources used. A company engaged in greenwashing thus seeks to suggest that their handling of natural resources for an event is better than it actually is. A final feature of greenwashing is (e) the concentration on areas that dominate public discussion, such as the reduction of $\mathrm{CO}_{2}$ emissions, the decrease in the consumption of resources or the waste reduction at events. These areas are then used to stagily demonstrate the eco-friendly image of a company. Areas in which the company performs less environmentally friendly are - in contrast-rather neglected in the communication processes (Fliegelmann, 2009; Polonsky et al., 2010).

\subsection{Current Approaches to Avoid Greenwashing in Event Marketing}

This section seeks to identify fundamental approaches of how to avoid greenwashing in event marketing. This is achieved in two steps. First, relevant journals related to event marketing were identified. The selection included journals published between 1992 and 2017 in the areas of tourism, leisure and hospitality management and listed in the Scientific Journal Rankings (Scimago Journal \& Country Rank). All 79 journals identified were then reviewed for the keywords "Greenwashing" and "Greenwash" in the title and the abstract. In addition, related working and conference papers were included. As demonstrated in Table 2, event-related journals have rather neglected the topic of greenwashing to date. Overall, only eight journals have published papers related to the topic. In total, eight articles dealt with the issue in the abstract and two articles in the headline and the abstract. These results highlight that greenwashing is neither a relevant nor an accepted topic within the event marketing literature (Baziilier \& Vauday, 2009; Lyon \& Maxwell, 2011).

As such, related discussions appear to take place in other journals without a focus on events. As a consequence, the radius of the literature analysis was expanded to a second complementary search in journals that include "Greenwashing" and "Greenwash". Databases searched included Scholar, Pro-Quest, EBSCO, Web of Science, Science Direct, ABI/Inform Global database, and Sage. In addition to the eight tourism/event/hospitality related journals a total of 27 further journals with 44 papers were identified (see Table 2). Most articles (25 percent) were published in the "Journal of Business Ethics" and in "Organization \& Environment" (5.77 percent) in the last ten years and 9.62 percent were working and conference papers.

Table 2. Research output of the "greenwashing" and "greenwash" analysis from January 1992 until June 2017 (alphabetical and $\mathrm{N}=52$ by journal \& conference papers)

\begin{tabular}{|c|c|c|}
\hline Step 1: Journals related to Event Marketing & $\begin{array}{l}\text { Papers with "Greenwashing"/ } \\
\text { "Greenwash" in the main title }\end{array}$ & $\begin{array}{l}\text { Papers with "Greenwashing"/ } \\
\text { "Greenwash" in the abstract }\end{array}$ \\
\hline International Journal of Contemporary Hospitality Management & 1 & 2 \\
\hline International Journal of Culture, Tourism, and Hospitality Research & 0 & 1 \\
\hline International Journal of Hospitality Management & 0 & 1 \\
\hline Journal of Sustainable Tourism & 1 & 2 \\
\hline Managing Leisure & 0 & 1 \\
\hline Worldwide Hospitality and Tourism Themes & 0 & 1 \\
\hline \multicolumn{3}{|l|}{ Step 2: Journals include "Greenwashing" / "Greenwash" } \\
\hline Akademy of Management (ACAD MANAGE PROC) & 1 & 1 \\
\hline Business and Society & 1 & 1 \\
\hline Business Ethics: A European Review & 1 & 1 \\
\hline California Management Review & 1 & 1 \\
\hline Corporate Social Responsibility and Environmental Management & 1 & 1 \\
\hline Critical Perspective on Accounting & 1 & 1 \\
\hline Fordham Urban Law Journal & 1 & 1 \\
\hline Forthcoming in Corporate Finance & 1 & 1 \\
\hline Global Environment Change & 1 & 0 \\
\hline International Journal of Advertising & 1 & 1 \\
\hline International Business Research & 1 & 1 \\
\hline $\begin{array}{l}\text { International Journal of Agricultural Resources, Governance and } \\
\text { Ecology }\end{array}$ & 1 & 1 \\
\hline International Journal of Business, Economics and Law & 1 & 1 \\
\hline International Journal of Business Studies - Special Edition & 1 & 1 \\
\hline International Journal of Business \& Economics Research Journal & 1 & 1 \\
\hline International Journal of Innovation and Sustainable Development & 1 & 1 \\
\hline Journal of Advertising & 1 & 1 \\
\hline Journal of Business Ethics & 11 & 13 \\
\hline Journal of Business \& Industrial Marketing & 1 & 1 \\
\hline
\end{tabular}




\begin{tabular}{lll}
\hline Journal of Business Research & 1 & 1 \\
Journal of Economics \& Management Strategy & 1 & 1 \\
Journal of International Business and Entrepreneur Development & 1 & 1 \\
Journal of Organizational Change Management & 1 & 1 \\
Public Relations View & 1 & 1 \\
Organization \& Environment & 3 & 3 \\
Quality and Quantity & 1 & 1 \\
Working Paper and Conference Papers & 5 & 5 \\
\hline
\end{tabular}

Next, the identified papers were allocated to five approaches to avoid greenwashing (Tab. 3). These five approaches are discussed below.

Table 3. Approaches that could lead to avoid greenwashing in event marketing

\begin{tabular}{|c|c|c|c|}
\hline Approach & Source & No. & Percent \\
\hline $\begin{array}{l}\text { 1. Identifying Greenwashing } \\
\text { and effects through } \\
\text { measurements }\end{array}$ & $\begin{array}{l}\text { Munshi/Kurian, 2005; Lyon/Maxwell, 2006; Marquis/Toffel, 2011, Walker/Wan, } \\
\text { 2012; Chen/Chang, 2013; Lyon/Montgomery, 2013; Chen et al., 2014; Nyilasy et al., } \\
\text { 2014; DeVries et al., 2015; Rahman et al., 2015, Smith/Xavier, 2015; Xingqiang, } \\
\text { 2015, Berrone et al., 2016; Font et al., 2016; Avicilar/Demirgünes, 2017; Hoepner et } \\
\text { al., 2017; Kassinis/Panayiotou, } 2017\end{array}$ & 17 & 32,69 \\
\hline 2. Using Internal Rules & Ramus/Montiel, 2005; Jones, 2012; Blome et al., 2017 & 3 & 5,77 \\
\hline $\begin{array}{l}\text { 3. Creating a (Multi-) } \\
\text { Stakeholder Approach }\end{array}$ & $\begin{array}{l}\text { Polansky, 1995; Cumming, 2001; Polansky, 2010; Delmas/Burbano, 2011; Insch, } \\
\text { 2011; Schielke/Fantapíe Altobelli, 2012; Mahoney et al., 2013; } \\
\text { Bowen/Aragon-Correa, 2014; Fernando et al., 2014; Kim/Lyon, 2014; bin Shahudin } \\
\text { et al., 2015; Guo et al., 2015; Testa et al., } 2017\end{array}$ & 14 & 26,92 \\
\hline $\begin{array}{l}\text { 4. Realignment according to } \\
\text { government regulation }\end{array}$ & $\begin{array}{l}\text { Lightfoot/Burchell, 2004; Lambertini et al., 2014; Smith/Font, 2014; Gosselt et al., } \\
2017\end{array}$ & 4 & 7,69 \\
\hline 5. Eco-labelling & $\begin{array}{l}\text { Laufer, 2003; Fliegelmann, 2009; Polansky et al., 2010; Self et al., 2010; Chan, 2013; } \\
\text { George, 2013; Lyon/Montgomery, 2015; Parguel et al., 2011; Geerts, 2014; } \\
\text { Parguel/Benoit-Moreau, 2014; Thomas, 2014, Parguel et al., 2015; Roulet/Touboul, } \\
2015\end{array}$ & 14 & 26,92 \\
\hline
\end{tabular}

\subsubsection{Identifying Greenwashing and its Impacts through Measurement}

The measurement and determination of greenwashing is concerned with the question how greenwashing can be identified and quantified based on corporate and product communication (e.g., Chen \& Chang, 2013; Chen et al., 2014; Laufer, 2003). Horiuchi \& Schuchard (2009) suggested a list with 14 questions to investigate whether a company is practicing greenwashing or not. The questions are divided into "impact", "alignment" and "communication". Applying these questions helps to determine what kind of intentions a company is pursuing, which people have been integrated and how the communication towards the customers has been designed. E.g., Chen, Lin, \& Chang (2014) used a shortened version of five questions to identify potential misleading behaviour of a company towards their customers.

This approach can be regarded as a starting point, which helps to make greenwashing visible. It may also assist in the set-up of a potential greenwash-index (Schmidt \& Donsbach, 2012) that could be integrated as an indicator in the ongoing event reporting.

Nyilasy, Gangadharbatla, \& Paladino (2014) investigated the impacts on customers' attitudes against brands that practice greenwashing. They demonstrate that an inconsistent relation between advertising with environmental content and the actual environmental performance of a company can have negative impacts on customers' attitudes towards the brand, thus damaging the brand. Hence, it becomes imperative for event controlling to regularly measure the attitude towards the brand and to determine the actual environmental performance of a company including a comparison of both values. Similarly, Bos (2017) discovered national differences towards greenwashing and called for further studies measuring the impacts of greenwashing based on national characteristics.

\subsubsection{Developing and Applying Internal Rules}

This approach considers the development and use of internal rules by the company, based on its own environmental policies (e.g., Blome, Foerstl, \& Schleper, 2017; Jones, 2012; Ramus \& Montiel, 2005). It can be of interest for event marketers to precisely formulate internal guidelines to avoid greenwashing and to support 
brand strength simultaneously. The explicit ban of greenwashing in event marketing could help to avoid negative consequences for brand personality. An example in this context is the code of conduct of the National Association of State Procurement Officials (NASPO) in the USA. Every NASPO member and supplier who registered for the 2013 NASPO how to market state governments meetings, was asked to agree to abide by the following code of conduct: "Suppliers shall conduct themselves in a manner that promotes the highest ethical standards and avoid activities and behaviors that would place, or even appear to place, a NASPO member in a conflict of interest" (NASPO, 2013).

To avoid greenwashing in the event industry, such codes of conduct could also be applied to event suppliers, while event marketers could integrate these defined rules into their success monitoring. Ramus and Montiel (2005), however, criticised the approach of setting up internal rules. They regarded them as ineffective since they are not legally binding and therefore claimed that this would be just another form of greenwashing. Similarly, Paillé \& Raineri (2015) highlighted that a company's orientation towards environmental policy does not necessarily lead to more environmental activities, because it very much depends on how the employees are supported during the implementation.

\subsubsection{Creating A (multi-)stakeholder Approach}

This approach demonstrates how greenwashing can be avoided through the integration of different stakeholders, such as NGO's, managers, or politicians (e.g., Delmas \& Burbano, 2011; Fernando, Suganhi, \& Sivakumanran, 2014; Testa, Boiral, \& Iraldo, 2015). Stakeholders are given the opportunity to introduce their knowledge to joint discussions and may thus also prevent the emergence of greenwashing through integration. In the field of events, the importance of stakeholders for sustainability issues has long been recognised and the necessary commitment of all actors involved in the value creation process has been strongly highlighted. Almost all checklists and guidelines for sustainable events (see Table 5) contain clear references.

For example, the "Major Event Greening Guide" of the New Zealand Ministry for the Environment (2010, p. 8) states: "Identifying and involving key stakeholders early is critical to a successful greener event. Many stakeholders can make a valuable contribution to developing and implementing the strategy and action plan, especially those also involved in delivering the event." Green Globe (2016), a global certification for sustainable tourism, also emphasises the importance of a well-written communications strategy for a company to inform stakeholders about sustainable policies, programmes and initiatives. It hence is extremely important " $\ldots$ that all stakeholders including management, employees, customers and the local community understand the business's goals and objectives, why they're important and how they can positively contribute to the business's efforts in each of their individual roles."

Similarly, a number of event studies have used stakeholder theory (Freeman, 1984) to illustrate the salience of different stakeholders when organizing sustainable events (e.g., Fairley, Tyler, Kellet, \& D'Elia, 2011; Hede, 2008). In this context, Sherwood (2007) emphasises that "Businesses have also been under pressure from a diverse range of internal and external stakeholders such as employees, communities, environmental groups and government, in order to be more accountable, responsible and transparent in relation to measuring and reporting on their performance" (p. 2). The increasing pressure by the public and the many stakeholders can thus help event organisers (and other actors involved in the process) to act more sustainably and are therefore able to limit greenwashing aspects a priori. Yet, different studies (e.g., Schielke \& Altobelli, 2012; Testa et al., 2015; Wood, 2015) have demonstrated that individual stakeholders (e.g., suppliers or consumers) can create pressure to support or prevent greenwashing activities. Thus, there is no guarantee that a multi-stakeholder approach is always effective to avoid greenwashing in event marketing.

\subsubsection{Realignment according to Laws and Statutory Regulations}

Statutory regulations provide opportunities for event marketing to avoid greenwashing. In a very recent study, Gosselt, van Rompay \& Haske (2017) found that by "introducing an external multilevel rating system by governmental law" (p. 1) ..." more favorable consumer responses (including brand attitude, corporate credibility, purchase intention, and scent experience)" (p. 9) could be induced which "might well prove to be an effective tool for reducing greenwashing and contributing to a truly responsible climate." (p. 11). In the event industry such a rating system driven by the governmental law does not exist. However, different local law initiatives by different countries are in place. In Germany, this includes for example the Law on Unfair Competition (UWG §1 and §3) which deals with environmental advertising. The law aims at protecting competitors, consumers and other market participants against unfair business practices. Paragraph 5 of the UWG states: "A commercial act is misleading if it contains untruthful information, [...]" (Federal Ministry of Justice and Consumer Protection, status as of 2013). According to the UWG, greenwashing or misleading brand communication is principally 
prohibited. Since the law does, however, not adequately address the issue of greenwashing and several parts are formulated rather vaguely and imprecisely, only a limited amount of legal actions can be taken against misleading brand communication. The UWG thus only offers a very generic approach to avoid greenwashing in event marketing. It should, for example, be ensured that eco-friendly statements about the product and the brand correspond to the actual corporate values of the company.

Overall, the responsible event manager needs to carefully pay attention to all forms of corporate communication to avoid greenwashing and should also consider previous court decisions (e.g., from the Federal Court of Justice). Different judicial decisions on how to deal with greenwashing exist in different countries (e.g., State of California Department of Justice, 2012) and these legal frameworks need to be considered.

\subsubsection{Applying Eco-labelling}

A widespread approach to avoid greenwashing is "the use of environmental certification by trusted parties, a process often known as eco-labelling" (Lyon \& Montgomery, 2015, p. 240). For example, the Green Guides of the Federal Trade Commission (FTC, 2012) contain various suggestions for marketers on how to avoid greenwashing. Paragraph $\$ 260.5$ of the FTC deals for example with "carbon offsets" and suggests statements which should be used to effectively communicate about emission reductions. Over the past few years, the event industry has developed an abundance of voluntary guidelines, regulations and checklists to help stakeholders to act more sustainably. Table 4 presents a selection of such guidelines.

Table 4. Sustainable regulations and guidelines in the context of events (extract only)

\begin{tabular}{|c|c|}
\hline Official guideline, rule or norm & Description \\
\hline Green Globe & $\begin{array}{l}\text { - established for the travel \& tourism industry (worldwide) } \\
\text { - based on international standards and agreements (e.g., ISO 9001/14001/19011, Agenda 21) } \\
\text { - } 41 \text { certification criteria and over } 300 \text { indicators (depending on the form of organization) } \\
\text { - cooperation with the German Convention Bureau (GCB), the European Association of Event Centres } \\
\text { (EVVC) and the Association of German Event Managers (VDVO) } \\
\text { www.greenglobe.com }\end{array}$ \\
\hline EU-Eco-regulation & $\begin{array}{l}\text { The European Union regulation No. } 834 / 2007 \text { of the European Council on organic production of } \\
\text { agricultural products and indications defines how agricultural products and foods that are designated as } \\
\text { ecological products must be cultivated. } \\
\text { https://www.bmel.de/SharedDocs/Downloads/Landwirtschaft/OekologischerLandbau/834_2007_EG_O } \\
\text { eko-Basis-VO.html }\end{array}$ \\
\hline EMAS & $\begin{array}{l}\text { The Eco-Management and Audit Scheme, a voluntary environmental management instrument } \\
\text { developed by the European Commission, which enables organizations to assess, manage and } \\
\text { continuously improve their environmental performance. } \\
\text { http://ec.europa.eu/environment/emas/index_en.htm }\end{array}$ \\
\hline $\begin{array}{l}\text { APEX/ASTM Environmentally } \\
\text { Sustainable } \\
\text { Meeting Standards }\end{array}$ & $\begin{array}{l}\text { Standards developed in collaboration between APEX (the Convention Industry Council's Accepted } \\
\text { Practices Exchange) and ASTM (An ANSI certified international standard development organization) } \\
\text { that can be implemented to create a more sustainable meetings or events. } \\
\text { http://www.gmicglobal.org/?page=APEX }\end{array}$ \\
\hline
\end{tabular}

As an alternative to setting up internal rules and in response to the critical remarks by Ramus \& Montiel (2005), the rules set out in DIN ISO EN 14001 (Beuth, 2015) are much more accepted. This norm assesses and certifies a firm's environmental management system and can lead to an optimisation process within which the company constantly develops and grows. In terms of greenwashing, the regulations DIN EN ISO 14020:2002-02, DIN EN ISO 14025:2011-10, DIN EN ISO 14029 and DIN EN ISO 14020:2009:11 are particularly relevant. They contain specific standards on how to avoid greenwashing, for example by avoiding generalised statements such as "sustainable" or "environmentally friendly".

In the events context, ISO 20121: Events Sustainability Management System is a management system standard that seeks to provide a framework to manage an event's sustainability issues (Jones, 2014). Implementing ISO 20121 starts with the definition of the organisation's governing principles of sustainable development. Particular emphasis is placed on the integration of key stakeholders. The norms then help to identify and evaluate key sustainability issues and to support the establishment of implementation policies, procedures and processes. In order to do so, adequate resources and the appropriate infrastructure needs to be provided. The process of achieving the set objectives and targets has to be constantly monitored, measured, clearly communicated and documented. Event organisations can demonstrate voluntary conformity with ISO 20121 by first party self-declaration, second party confirmation of conformance (by parties having an interest in the organisation, 
such as clients) or by certification through an independent third party (e.g., a certification body).

In contrast to other system standards (ISO 14001, ISO 9001), which are not specific to any particular industry sector, ISO 20121 was created specifically for the event industry and can be applied to an organisation, event organiser, a single event or event venue, the event owner, sponsor or supplier. The norm is regarded as a useful system to "ensure continuous performance improvement and strategic management of issues rather than an ad hoc approach" (Jones, 2014, p. 353). However, critics describe ISO 20121 as a rather "abstract management tool" which does not include many substantive requirements for events. As such, specific requirements for the sustainable organisation and implementation of events are only listed in the non-binding appendix that contains rather broad suggestions (Große Ophoff, 2016). Große Ophoff (2016) states: "If you replaced the word "event" with "car wash site" [in ISO 20121], you would immediately get a 98\% analogical norm for sustainable car wash sites" (p. 23). Similarly, the practicalities of incorporating such an extensive system, particularly for smaller events, festivals and venues, are questionable since they often neither have the man power nor the budget to do so (Ashdown, 2010).

In addition, other sustainable initiatives have recently been implemented in the event industry, such as the training course to become a "sustainability adviser" offered by the German Convention Bureau. Also, a large variety of "green awards" (for example "A Greener Festival Award", the IMEX-GMIC Green Awards, the Meeting Experts Green Awards, The Green Operations Award by European Festivals Awards and many more) are awarded annually to players of the industry to honour their sustainability efforts. Ramus \& Montiel (2005), however, criticise these awards and hold that giving awards in itself already represents a form of greenwashing. This could be the case if, for example, the award is given only for specific event marketing activities while the majority of marketing activities are not sustainable.

In summary, there is a wide variety of options for actors of the event industry to become more sustainable by following guidelines and internal policies, applying for prizes and awards or taking part in further training courses. However, all these initiatives are on a voluntarily basis. In addition, most documents, guidelines and policies are formulated rather broadly and non-specifically. Finally, the sheer amount of different guidelines and regulations leads to complexity and a challenge for all players involved in the event industry, in particular for (Große Ophoff, 2012):

(1) the event "producing" actors on one hand (e.g., event organisers, venues), as it is hard to choose the guideline or award that suits the organisation and organisational culture best and that helps to build trust and credibility.

(2) the event participants or clients on the other hand, as it is difficult to compare these guidelines / awards and to assess their validity and credibility.

\section{Discussion, Implications and Further Research}

\subsection{Discussion}

The aim of the systematic review was to assess the current state of approaches to avoid greenwashing in the event marketing context. The results of the literature analysis have demonstrated that very different approaches exist. The most feasible approaches are related to the internal organisation (i.e., approaches 1, 2, 3 and 5). Here, companies can engage in initiatives (e.g., internal rules) in the short or medium term. It is, however, important that these approaches are applied consistently in order to be effective.

In the past, there have been numerous examples of greenwashing in the event industry, particularly in the context of hidden goal conflicts (see Table 1). For example, many companies presented themselves as particularly sustainable at an exhibition or trade show, but disposed their entire carpet or floor cover directly after the exhibition's closing. Other examples include event venues that provide recycling containers but refuse to spend money on recycling companies to pick up different sorts of garbage. Attendees carefully separate their rubbish and feel good about helping out when, in fact, it all goes to the landfill unseparated (Zavada, 2013). Thus, an increase in self-commitment and reliability of the actors in event marketing will be necessary in the future (see Große Ophoff, 2016). At the same time event manager may find themselves in a dilemma. On one hand they act green by doing activities like energy recovery/saving, recycling or reusing resources. On the other hand by acting green they are able to do greenwashing (compare Tab. 1). As mentioned in the introduction you first need an environmentally friendly product or service to enter the scope of greenwashing (terrachoice, 2010). Thus, to behave green not necessarly leads to a feasible green framework.

The multi-stakeholder approach is more complex and requires a cultural change in the organisation in order to integrate the various interests and opinions of other (especially critical) stakeholders. This would significantly 
increase the time and effort to plan and host an event. Although this approach appears to be promising since a variety of opinions are taken into account, Testa et al. (2015) express their concerns. Greenwashing would be discussed more extensively with all stakeholders, which in turn could lead to more disagreement from individual actors and thus spark a more critical dialogue about greenwashing.

The approaches 4 and 5 seem to be more binding and their external perception is thus more credible. It would, however, also be important to focus more strongly on the quality of these principles, awards, and guidelines instead of prioritising quantity-related aspects (i.e., continuously developing new guidelines). A large number of these guidelines are also still subject to self-disclosure and self-certification which hinders their effectiveness.

Additionally, these guidelines are often not very profound and therefore relatively easy for almost all companies to comply with (Große Ophoff, 2016). There is a growing trend by event organisers and other players of the event industry to "quickly" apply these guidelines and to then use them as evidence for acting sustainably or even being sustainable (Milne \& Gray, 2012; Norman \& MacDonald, 2004). Managers thus tend to regard sustainability as being achievable with little or no challenge to business-as-usual. A more holistic and insistent approach is needed in the future in order to implement sustainability more profoundly within all areas and during the entire process of event organisation, in order to limit the threat of greenwashing a priori. Finally, country-specific peculiarities such as court decision based on the UWG (paragraph 1,3, and 5), awards on a national level (e.g., the German Sustainability Award), or optional guidelines for individual countries need to be better considered and assessed.

\subsection{Theoretical Contributions and Practical Implications}

Greenwashing in event marketing has not received much interest to date and few practitioners are aware about the potential negative consequences involved. Lyon \& Montgomery $(2015$, p. 244) emphasise that the "study of greenwash is still young and much important work remains to be done." This article has provided an overview on the different characteristics and features of greenwashing and also discussed the consequences. It thus assists practitioners to better detect and recognise greenwashing aspects at events in order to then actively help to contain them. Increasing attention and reporting of greenwashing behaviour of actors within the event industry can help to expose dubious practices and "black sheep" within the industry and raise awareness of this topic among industry players. At the same time, this will assist in reducing greenwashing behaviour which in times of global climate change is increasingly important.

This research has also conducted a systematic analysis of current approaches to avoid greenwashing as well as their limitations. In doing so, it became apparent that no universal approach on how to avoid greenwashing currently exists. Event practitioners do have a variety of options to avoid greenwashing, as demonstrated in this article. In particular, internal rules and policies or official eco labels can be applied. Since nearly of these policies and labels are based on self-commitment and self-disclosure, it is, however, very important for companies to act with caution and to apply a high degree of transparency throughout the process so as to avoid the process to be some form of greenwashing in itself. In addition, an independent controlling agency or working group could be appointed within the company to ensure a high degree of reliability and trustworthiness. This would also encounter the criticism by Ramus \& Montiel (2005) outlined earlier. Finally, it is important to constantly support and guide all employees throughout the process of applying internal policies or eco labels since the success of implementing these policies and labels very much depends on the active commitment of all employees involved (Paillé \& Raineri, 2015).

Another promising approach is the multi-stakeholder approach. Previous studies (e.g., Fairley, Tyler, Kellet, \& D'Elia, 2011; Hede, 2008) have demonstrated how this approach can help event organisers to increase the level of sustainability of their events since the integration of a wide variety of stakeholders induces critical debate and discussions and helps to scrutinise, challenge and question different aspects within the event organisation process A stronger integration of all event stakeholders might thus also help to reduce and avoid greenwashing in the future a priori. Further research is, however, needed on how multi-stakeholder integration can be applied effectively in the context of greenwashing around events.

A general strengthening of laws and statutory regulations would also be desirable to prevent greenwashing. This particularly applies in the context of brand communication. As of 2017, the "directive on disclosure of non-financial and diversity information by certain large companies" of the European Parliament (The European Parliament, 2014) is a good example of how policy and lawmakers can exhaust all possibilities to limit greenwashing. Companies with more than 500 employees are then required to disclose non-financial information (for example in the fields of environment and health, human resources, social affairs and society, value creation processes with respect to material and information flows, human rights and combating corruption and bribery) 
by means of an EU directive on disclosure. In the long term, this directive is likely to lead to a stronger application of sustainable principles in the event industry and hopefully prevent greenwashing effectively. According to the decision of the European Parliament it would be useful to replace the concept of greenwashing in the event marketing with "CSR-Washing" (Pope \& Wæraas, 2015). This would take into account not only the ecological but also the economic and social dimension of sustainability. Discussing greenwashing in the context of CSR (Corporate Social Responsibility) would also allow seeing it less as a communication but rather as an overall strategy of the company (Bazillier \& Vauday, 2009).

As such, an increasing amount of organisations have implemented CSR strategies to improve pro-environmental attitudes, behaviour and habits of individuals in the workplace (Baumgartner \& Winter, 2014; Law, Hills, \& HangHau, 2017). Incorporating "CSR-Washing" into a company's environmental education can help to raise awareness and build consciousness of employees towards greenwashing and the multifarious consequences involved as well as on instruments and habits on how to avoid them. It would also address the gap between sustainable awareness/knowledge and the actual sustainable behaviour within organisations (Kollmuss \& Agyeman, 2002), a problem also well-discussed in environmental psychology literature (e.g., Bamberg \& Möser, 2007; Fietkau \& Kessel, 1981). Overall, it would help to develop and encourage a transition to a greener corporate culture (Law, Hills, \& HangHau, 2017).

\subsection{Limitations and Future Research}

A first limitation is that this research has focused on German and English - language research papers. By including other languages and social contexts, a greater global perspective could be achieved (e.g., Warren \& Becken, 2017). Further limitations are based on the subjective process of the segmenting apply in the approaches that could to avoid greenwashing in event marketing.

Also, further qualitative and quantitative (event) management studies around greenwashing would be desirable in the future to deepen our understanding from a practical point of view. For example, an interesting question that still merits discussion and insight is how well educated corporate leaders and marketing strategists are in terms of greenwashing? (cf. Wood, 2015). Future studies should also examine the effectiveness of the different approaches outlined earlier. In this context, combined approaches might be a potential scenario. Experimental research methods could be used to test these approaches under laboratory conditions.

In addition, there is a need to more thoroughly examine social media as a possible tool to limit the extent of greenwashing (Hoepner, Dimatteo, Schaul, Pei-Shan, \& Musolesi, 2017; Lyon \& Montgomery, 2013) in the event marketing. Especially "trace users' response and attitudes to website changes and document the possible multiplicity of interpretations" (Kassinis \& Panayiotou, 2017, p. 31) could be analysed by future work, because of the importance of visual imagery.

Greenwashing can jeopardise the credibility of all companies which address environmental aspects in their external event communication (Alves, 2009; Chen et al., 2014). There is the imminent risk that customers who are confronted with perpetual greenwashing activities by events react with disorientation towards environmental information, which ultimately leads to a general decrease in confidence towards green statements (Chen \& Chang, 2013; Hamann \& Kapelus, 2004). More research is needed that take care about welfare impacts of greenwashing (e.g., Lyon \& Montgomery, 2015) at events, because there is the imminent risk that customers who are confronted with perpetual greenwashing activities by companies react with disorientation towards environmental information, which ultimately leads to a general decrease in confidence towards green statements (Chen \& Chang, 2013; Hamann \& Kapelus, 2004) and a green economy. As a consequence, greenwashing might hinder a transformation process to a more sustainable economy which we urgently need.

Finally, it would be valuable to conduct a longitudinal study and investigate why greenwashing is continuously present at repeating events (such as the Olympic Games) over the years and how this can be effectively prevented in the future (Boykoff \& Mascarenhas, 2016). In summary, greenwashing is still relatively under-represented in current scholarly and practical event debate. Further research is needed to address the challenges that lie ahead in a world facing increasing environmental challenges.

\section{References}

Alves, I. M. (2009). Green spin everywhere: How greenwashing reveals the limits of the CSR paradigm. Journal of Global Change and Governance, 2(2), 1-26.

Ashdown, H. (2010). The Sustainable Future of Music Festivals: How can new policy instruments and voluntary guidance tools help music festivals become more sustainable? Lund University, Sweden. Retrieved from http://lup.lub.lu.se/luur/download?func $=$ downloadFile\&recordOId $=1747426 \&$ fileOId $=1747430$ 
Avcilar, M. Y., \& Demirgünes, B. K. (2017). Developing perceived greenwash index and its effect on green brand equity: A research on gas station companies in Turkey. International Business Research, 10(1), 222-239. https://doi.org/10.5539/ibr.v10n1p222

Bamberg, S., \& Möser, G. (2007). Twenty Years after Hines, Hungerfood and Tomera: A new meta-analysis of psycho-social determinants of pro-environmental behaviour. Journal of Environmental Psychology, 27(1), 14-25. https://doi:10.1016/j.jenvp.2006.12.002

Baumgartner, R. J., \& Winter, T. (2014). The sustainability manager: a tool for education and training on sustainability management. Corporate Social Responsibility and Environmental Management, 21(3), 167-174. https://doi:10.1002/csr.1313

Bazillier, R., \& Vauday, J. (2009). The Greenwashing Machine: Is CSR more than Communication. DR LEO, 2009-10.

Berrone, P., Fosfuri, A., \& Gelabert, L. (2015). Does greenwashing pay off? Understanding the relationship between environmental actions and environmental legitimacy. Journal of Business Ethics, 8, 1-17. https://doi.org/10.1007/s10551-015-2816-9

Beuth. (2015). Norm ISO 14001: Umweltmanagementsysteme: Anforderungen mit Anleitung zur Anwendung. Berlin, Germany: Beuth.

bin Shahudin, M. H., bin Md Shah, M. A. M., \& bin Mahzan, S. (2015). Modelling the greenwashing behavior among Malaysian Firms: The roles of organizational and individual drivers. International Journal of Business, Economics and Law, 7(2), 8-12.

Blome, C., Foerstl, K., \& Schleper, M.C. (2017). Antecedents of green supplier championing and greenwashing: An empirical study on leadership and ethical incentives. Journal of Cleaner Production, 152, 339-350. https://doi.org/10.1016/j.jclepro.2017.03.052

Boiral, O., Heras-Saizarbotoria, I., \& Testa, F. (2016). SA8000 as CSR-Washing? The role of stakeholder pressures. Corporate Scoial Responsibility and Environmental Management, 24, 57-70. https://doi.org/10.1002/csr.1391

Bos, M. (2017). Nationality and greenwashing: Differences between The Netherlands and Suriname on consumer attitude, University of Twente. Retrieved from http://essay.utwente.n1/71913/

Bowen, F., \& Aragon-Correa, J. A. (2014). Greenwashing in corporate environmentalism research and practice: The importance of what we say and do. Organization \& Environment, 27, 107-112. https://doi.org/10.1177/1086026614537078

Boykoff, J., \& Mascarenhas, G. (2016). The Olympics, sustainability, and greenwashing: The Rio 2016 Summer Games. Capitalism Nature Socialism, 27(2), 1-11. https://doi.org/10.1080/10455752.2016.1179473

Bruno, K. (1992). The Greenpeace book of greenwash. Retrieved from http://research.greenpeaceusa.org/?a=view\&d=4519

Chen, Y. S. (2010). The drivers of green brand equity: Green brand image, green satisfaction, and green trust. Journal of Business Ethics, 93(2), 307-319. https://doi.org/10.1007/s10551-009-0223-9

Chen, Y. S., \& Chang, C. H. (2013). Greenwash and green trust: The mediation effects of green consumer confusion and green perceived risk. Journal of Business Ethics, 114, 489-500. https://doi.org/10.1007/s10551-012-1360-0

Chen, Y. S., Lin, C. L., \& Chang, C. H. (2014). The influence of greenwash on green word-of-mouth (green WOM): The mediation effects of green perceived quality and green satisfaction. Quality and Quantity, 48, 2411-2425. https://doi.org/10.1007/s11135-013-9898-1

Cumming, J. F. (2001). Engaging stakeholders in corporate accountability programs: A cross- sectorial analysis of U.K. and transnational experience. Business Ethics: A European Review, 10, 44-52.

De Vries, G., Terwel, B. W., Ellemers, N., \& Daamen, D. D. L. (2015). Sustainability or profitability? How communicated motives for environmental policy affect public perceptions of corporate greenwashing. Corporate Social Responsibility and Environmental Management, 22(3), 142-154. https://doi.org/10.1002/csr.1327

Delmas, M. A., \& Burbano, V. C. (2011). The drivers of greenwashing. California Management Review, 54(2), 65-87. https://doi.org/10.1525/cmr.2011.54.1.64 
Fairley, S., Tyler, B. D., Kellett, P., \& D’Elia, K. (2011). The Formula One Australian Grand Prix: Exploring the triple bottom line. Sport Management Review, 14(2), 141-152. https://doi.org/10.1016/j.smr.2010.07.001

Federal Ministry of Justice and Consumer Protection. (2013). UWG. Retrieved from http://www.gesetze-im-internet.de/uwg_2004

Federal Trade Commission (FTC). (2012). Guides for the use of environmental marketing claims. Retrieved from

https://www.ftc.gov/policy/federal-register-notices/guides-use-environmental-marketing-claims-green-guide $\mathrm{s}$

Fernando, A. G., Suganthi, L., \& Sivakumanran. (2014). If you blog, will they follow? Using online media to set the agenda for consumer concerns on "greenwashed" environmental claims. Journal of Advertising, 32(2), 167-180. https://doi.org/10.1080/00913367.2013.841088

Fietkau, H. J., \& Kessel, H. (1981). Umweltlernen: Veränderungsmöglichkeiten des Umweltbewusstseins. Modell-Erfahrungen. Koenigstein, Germany: Hain.

Fliegelmann, J. E. (2009). The next generation of greenwash: Diminishing consumer confusion through a national ECO-Labeling Program. Fordham Urban Law Journal, 37(4), 999-1056.

Font, X., Elgammal, I., \& Lamond, I. (2017). Greenhushing: The deliberate under communicating of sustainability practices by tourism businesses. Journal of Sustainable Tourism, 25(7), 1007-1023. https://doi.org/10.1080/09669582.2016.1158829

Freeman, R. E. (1984). Strategic management: A stakeholder approach. Boston, MA: Pitman.

Furlow, N. (2010). Greenwashing in the new millennium. The Journal of Applied Business and Economics, 10(6), $22-25$.

Geerts, W. (2014). Environmental certification schemes: Hotel managers' views and perceptions. International Journal of Hospitality Management, 39, 87-96. https://doi.org/10.1016/j.ijhm.2014.02.007

George, A. (2013). Managing ski resorts: Perceptions from the field regarding the sustainable slopes charter. Managing Leisure, 8(1), 41-46. https://doi.org/10.1080/1360671032000075234

Gosselt, J. F., van Rompay, T., \& Haske, L. (2017). Won't get fooled again: The effects of internal and external" CSR ECO-Labeling. Journal of Business Ethics, 1-12. https://doi.org/10.1007/s10551-017-3512-8

Green Globe. (2016). Sustainable Management. Retrieved from http://greenglobe.com/?faqs=a-sustainable-management

Greenpeace. (2014). Athens 2004 disqualified from Green Olympics. Retrieved from http://www.greenpeace.org/international/en/news/features/athens-disqualified-from-green

Große Ophoff, M. (2012). Green Meetings \& Events: Nachhaltiges Tagen in Deutschland. In M. T. Schreiber (Ed.), Kongresse, Tagungen und Events: Potenziale, Strategien und Trends der Veranstaltungswirtschaft (pp. 173-186). München, Germany: Oldenbourg. https://doi.org/10.1524/9783486716054.173

Große Ophoff, M. (2016). Das DBU Zentrum für Umweltkommunikation. In M. Große Ophoff (Ed.), Nachhaltiges Veranstaltungsmanagement: Green Meetings als Zukunftsprojekt für die Veranstaltungsbranche (pp. 261-265). München, Germany: Oldenbourg.

Guo, R., Tao, L., Bingxin Li, C., \& Wang, T. (2015). A path analysis of greenwashing in a trust crisis among Chinese energy companies: The role of brand legitimacy and brand loyalty. Journal of Business Ethics, 140(3), 523-536. https://doi.org/10.1007/s10551-015-2672-7

Hamann, R., \& Kapelus, P. (2004). Corporate social responsibility in mining in Southern Africa: Fair $\begin{array}{lllll}\text { accountability or just greenwash? } & \text { Development, } & 47(3), & \text { 85-92. }\end{array}$ https://doi.org/10.1057/palgrave.development.1100056

Hede, A. M. (2008). Managing special events in the new era of the triple bottom line. Event Management, 11(1-2), 13-22. https://doi.org/10.3727/152599508783943282

Hoepner, A. G. F., Dimatteo, S., Schaul, J., Pei-Shan, Y., \& Musolesi, M. (2017). Tweeting about sustainability: can emotional nowcasting discourage greenwashing? Corporate Finance, 8(3\&4), 1-18. https://doi.org/10.2139/ssrn.2924088

Horiuchi, R., \& Schuchard, R. (2009). Understanding and preventing greenwash: A business guide. Futerra Sustainability 
www.futerra.co.uk/downloads/Understanding_and_Preventing_Greenwash.pdf

Insch, A. (2011). Conceptualization and anatomy of green destination brands. International Journal of Culture, Tourism and Hospitality Research, 5(3), 282-290. https://doi.org/10.1108/17506181111156970

Jones, D. R. (2012). Looking through the "greenwashing glass cage" of the green league table towards the sustainability challenge for UK universities. Journal of Organizational Change Management, 25(4), 630-647. https://doi.org/10.1108/09534811211239263

Jones, M. (2014). Sustainable event management: A practical guide (2nd ed.). Abingdon, UK: Routledge.

Jurnecka, R. (2011). Paris Passat Pairing: Volkswagen shows off NMS sketches on Facebook, Retrieved from http://www.motortrend.com/news/paris-passat-pairing-volkswagen-shows-off-nms-sketches-on-facebook-9 $665 /$

Kalafatis, S. P., \& Pollard, M. (1999). Green marketing and Ajzen's theory of planned behaviour: A cross-market $\begin{array}{lllll}\text { examination. Journal of Consumer } & \text { Marketing, }\end{array}$ https://doi.org/10.1108/07363769910289550

Kassinis, G., \& Panayiotou, A. (2017). Visuality as greenwashing: The case of BP and Deepwater Horizon. https://doi.org/10.1177/1086026616687014

Kim, E. H., \& Lyon, T. P. (2014). Greenwash vs. brownwash: Exaggeration and undue modesty in corporate sustainability disclosure. Organization Science, 26(3), 705-723. https://doi.org/10.1287/orsc.2014.0949

Kollmuss, A., \& Agyeman, J. (2002). Mind the Gap: Why do people act environmentally and what are the barriers to pro-environmental behavior? Environmental Education Research, 8(3), 239-260. https://doi.org/10.1080/13504620220145401

Lambertini, L., Pignataro, G., \& Tampieri, A. (2014). Green consumers, greenwashing and the misperception of environmental quality. CREA Discussion Paper 2014-21. Retrieved from http://wwwfr.uni.lu/recherche/fdef/crea/publications2/discussion_papers

Lane, E. L. (2014). Greenwashing 2.0: Identifying a new paradigm through B-to-B threat matrices. In D. R. Cahoy \& J. E. Colburn (Eds.), Law and the Transition to Business Sustainability (pp. 141-153). Perspectives on Sustainable Growth. New York: Springer International Switzerland.

Laufer, W. S. (2003). Social accountability and corporate greenwashing. Journal of Business Ethics, 43(3), 253-261. https://doi.org/10.1023/A:1022962719299

Law, M. M. S., Hills, P., \& HangHau, B. C. (2017). Engaging employees in sustainable development: A case study of environmental education and awareness training in Hong Kong. Business Strategy and the Environment, 26, 84-97. https://doi.org/10.1002/bse.1903

Lightfoot, S., \& Burchell, J. (2004). Green hope or greenwash? The actions of the European Union at the World Summit on Sustainable Development. Global Environmental Change, 14, 337-344. https://doi.org/10.1016/j.gloenvcha.2004.07.002

Lyon, T. P., \& Maxwell, J. W. (2011). Greenwash: Corporate environmental disclosure under threat of audit. $\begin{array}{lllll}\text { Journal of Economics \& } & \text { Management }\end{array}$ https://doi.org/10.1111/j.1530-9134.2010.00282.x

Lyon, T. P., \& Montgomery, A. W. (2015). The Means and Ends of Greenwash. Organization \& Environment, 28, 223-249. https://doi.org/10.1177/1086026615575332

Lyon, T. P., \& Montgomery, A. W. J. (2013). Tweetjacked: The impact of social media on corporate greenwash. Journal of Business Ethics, 118(4), 747-757. https://doi.org/10.1177/1086026615575332

Mahoney, L. S., Thorne, L., Cecil, L., \& LaGore, W. (2013). A research note on standalone corporate social responsibility reports: Signaling or greenwashing? Critical Perspective on Accounting, 24(4-5), 350-359. https://doi.org/10.1016/j.cpa.2012.09.008

Marquis, C., \& Toffel, M.W. (2011). The globalization of corporate environmental disclosure: Accountability or greenwashing? Working Paper, 11-115. Retrieved from https://business.illinois.edu/business-administration/wp-content/uploads/sites/39/2014/09/marquis_paper.pd $\mathrm{f}$

Milne, M. J., \& Gray, R. (2012). W(h)ither ecology? The triple bottom line, the Global Reporting Initiative, and corporate sustainability reporting. Journal of Business Ethics, 118(1), 13-29. 
https://doi.org/10.1007/s10551-012-1543-8

Miras-Rodríguez, M., Carrasco-Gallego, A., \& Escobar-Pérez, B. (2015). Has the CSR engagement of electrical companies had an effect on their performance? A closer look at the environment. Business Strategy and Environment, 24(8), 819-835. https://doi.org/10.1002/bse.1848

Mitchell, V. W., \& Papavassiliou, V. (1999). Marketing causes and implications of consumer confusion. Journal of Product and Band Management, 8(4), 319-339. https://doi.org/10.1108/10610429910284300

Montoro-Rios, F. J., Luque-Martinez, T., \& Rodriguez-Molina, M.-A. (2008). How green should you be: Can environmental associations enhance brand performance? Journal of Advertising Research, 48(4), 547-563. https://doi.org/10.2501/S0021849908080

Munshi, D., \& Kurian, P. (2005). Imperializing spin cycles: A postcolonial look at public relations, greenwashing, and the separation of publics. Public Relations View, 31(4), 513-520. https://doi.org/10.1016/j.pubrev.2005.08.010

NASPO. (2013). How To Market to State Governments Meeting. Retrieved from https://www.naspo.org/dnn/Events/2013-Marketing-Meeting/Code-of-Conduct

New Zealand Ministry for the Environment. (2010). Major event greening guide: A practical guide to reducing the environmental impact of a major event. ME 1002. Retrieved from http://www.mfe.govt.nz/publications/sustainability/major-event-greening-guide

Norman, W., \& MacDonald, C. (2004). Getting to the bottom of the "Triple Bottom Line". Business Ethics Quarterly, 14(2), 243-262. https://doi.org/10.5840/beq200414211

Nyilasy, G., Gangadharbatla, G., \& Paladino, A. (2014). Perceived greenwashing: The interactive effects of green advertising and corporate environmental performance on consumer reactions. Journal of Business Ethics, 125(4). 693-707. https://doi.org/10.1007/s10551-013-1944-3

Paillé, P., \& Raineri, N. (2015). Linking perceived corporate environmental policies and employees eco-initiatives: The influence of perceived organizational support and psychological contract breach. Journal of Business Research, 68(11), 2404-2411. https://doi.org/10.1016/j.jbusres.2015.02.021

Parguel, B., \& Benoit-Moreau, F. (2014). The power of "executional greenwashing”. Evidence from the automotive sector. Lalonde Conference, May 2013, France.

Parguel, B., Benoît-Moreau, F., \& Larceneux, F. (2011). How sustainability ratings might deter "greenwashing": A closer look at ethical corporate communication. Journal of Business Ethics, 102(1), 15-28. https://doi.org/10.1080/02650487.2014.996116

Parguel, B., Benoit-Moreau, F., \& Russel, C. A. (2015). Can evoking nature in advertising mislead consumers? The power of "executional greenwashing". International Journal of Advertising, 34(1), 107-134. https://doi.org/10.1080/02650487.2014.996116

Polansky, M. J., Grau, S. L., \& Garma, R. (2010). The new greenwash! Potential marketing problems with carbon offsets. International Journal of Business Studies, 18(1), 40-54.

Polonsky, M. J. (1995). A stakeholder theory approach to designing environmental marketing strategy. Journal of Business \& Industrial Marketing, 10(3), 29-46. https://doi.org/10.1108/08858629510096201

Polonsky, M. J. (2010). Transformative green marketing: Impediments and opportunities. Journal of Business Research, 64(12), 1311-1319. https://doi.org/10.1016/j.jbusres.2011.01.016

Pope, S., \& Wæraas, A. (2015). CSR-Washing is rare: A conceptual framework, literature review, and critique. Journal of Business Ethics, 1, 1-21. https://doi.org/10.1007/s10551-015-2546-z

Rahman, L., Park, L., \& Geng-Qing Chi, C. (2015). Consequences of "greenwashing": Consumers' reactions to hotels' green initiatives. International Journal of Contemporary Hospitality Management, 27(6), 1054-1081. https://doi.org/10.1108/IJCHM-04-2014-0202

Ramus, C. A., \& Montiel, I. (2005). When are corporate environmental policies a form of greenwashing? Business and Society, 44(4), 377-414. https://doi.org/10.1177/0007650305278120

Roulet, T. J., \& Touboul, S. (2015). The Intentions with which the road is paved: Attitudes to liberalism as determinants of greenwashing. Journal of Business Ethics, 128, 305-320. https://doi.org/10.1007/s10551-014-2097-8

Schermer, M. (2008). Organic policy in Austria: Greening and greenwashing. International Journal of 
$\begin{array}{llll}\text { Agricultural Resources, } \quad \text { Governance } & \text { and }\end{array}$ https://doi.org/10.1504/IJARGE.2008.016978

Schielke, S., \& Fantapíe Altobelli, C. (2012). Consumer greenwashing: Using the theory of planned behaviour to explain unethical consumer behaviour. Institut für Marketing Retrieved from https://www.hsu-hh.de/download-1.5.1.php?brick_id=6KghzMawrIDExelq

Schmidt, A., \& Donsbach, W. (2012). „Grüne“ Werbung als Instrument für „schwarze“ Zahlen. Eine Inhaltsanalyse ökologischer Anzeigen aus deutschen und britischen Zeitschriften 1993 bis 2009, Publizistik, 57, 75-93. https://doi.org/10.1007/s11616-012-0140-2

Self, R. M., Self, D. R., \& Bell-Haynes, J. (2010). Marketing tourism in the Galapagos Islands: Ecotourism Or Greenwashing? International Business \& Economics Research Journal, 9(6), 111-126. https://doi.org/10.19030/iber.v9i6.590

Sherwood, P. (2007). A triple bottom line evaluation of the impact of special events: The development of indicators. Victoria University, Melbourne, Australia. Retrieved from http://vuir.vu.edu.au/1440/1/Sherwood.pdf

Smith, V. L., \& Font, X. (2014). Volunteer tourism, greenwashing and understanding responsible marketing using market signaling theory. Journal of Sustainable Tourism, 22, 942-963. https://doi.org/10.1080/09669582.2013.871021

Smith, V. L., \& Font, X. (2015). Marketing and communication of responsibility in volunteer tourism. Worldwide Hospitality and Tourism Themes, 7(2), 159-180. https://doi.org/10.1108/WHATT-12-2014-0050

State of California Department of Justice (2012). Greenwashing. Retrieved from https://oag.ca.gov/environment/greenwashing

TerraChoice. (2007). Greenwashing Report 2007: The Six Sins of Greenwashing: A Study of Environmental Claims in North American Consumer Markets. Retrieved from http://sinsofgreenwashing.com/findings/index.html

TerraChoice. (2009). Greenwashing Report 2009: The Sins of Greenwashing: Home and Family Edition. Retrieved from http://sinsofgreenwashing.com/findings/index.html

TerraChoice. (2010). Greenwashing Report 2010: The Seven Sins of Greenwashing: Environmental Claims in Consumer Markets. Retrieved from http://sinsofgreenwashing.com/findings/index.html

Testa, F., Boiral, O., \& Iraldo, F. (2015). Internalization of environmental practices and institutional complexity: Can stakeholder's pressures encourage greenwashing. Journal of Business Ethics, 1-21. https://doi.org/10.1007/s10551-015-2960-2

Testa, F., Iraldo, F., \& Daddi, R. (2017). The Effectiveness of EMAS as a Management Tool: A Key Role for the Internalization of Environmental Practices. Organization \& Environment, 1, 1-22. https://doi.org/10.1177/1086026616687609

The European Parliament. (2014). PE-CONS 47/14: Disclosure of non-financial and diversity information by certain large undertakings and groups. Retrieved from http://register.consilium.europa.eu/doc/srv?l=EN\&f=PE\%2047\%202014\%20INIT

Thomas, J. R. (2014). Shades of green: A critical assessment of greenwashing in social and environmental business performance report. Journal of International Business and Entrepreneurship, 7(3), 245-252. https://doi.org/10.1504/JIBED.2014.063092

Tilt, C. A. (1994). The influence of external pressure groups on corporate social disclosure: Some empirical $\begin{array}{lllll}\text { evidence. Accountability, Auditing \& Accountability Journal, 7, } & \text { 47-72. }\end{array}$ https://doi.org/10.1108/09513579410069849

Vollero, A., Palazzo, M., Siano, A., \& Elving, W.J.L. (2016). Avoiding the greenwashing trap: Between CSR communication and stakeholder engagement. International Journal of Innovation and Sustainable Development, 10(2), 120-140. https://doi.org/10.1504/IJISD.2016.075542

Walker, K., \& Wan F. (2012). The harm of symbolic actions and green-washing: Corporate actions and communications on environmental performance and their financial implications. Journal of Business Ethics, 2019(2), 227-242. https://doi.org/10.1007/s10551-011-1122-4

Warren, C., \& Becken, S. (2017). Saving energy and water in tourist accommodation: A systematic literature review (1987-2015). International Journal of Tourism Resort, 19(3), 289-303. 
https://doi.org/10.1002/jtr.2112

Wood, M. E. (2015). Exploring Consumers' Experiences with Corporate Greenwashing. Dissertation, Walden University. http://search.proquest.com/openview/981bb401d652b6a57c6c0a5f5a0391c2/1?pq-origsite $=$ gscholar\&cbl=1 $8750 \&$ diss $=\mathrm{y}$

Xingqiang, D. (2015). How the Market Values Greenwashing? Evidence from China. Journal of Business Ethics, 128, 547-574. https://doi.org/10.1007/s10551-014-2122-y

Zavada, N. (2013). When it comes to green meetings: Never assume anything. MeetingsNet. Retrieved from http://meetingsnet.com/green-meetingscsr/when-it-comes-green-meetings-never-assume

\section{Copyrights}

Copyright for this article is retained by the author(s), with first publication rights granted to the journal.

This is an open-access article distributed under the terms and conditions of the Creative Commons Attribution license (http://creativecommons.org/licenses/by/4.0/). 